\title{
Effect of Municipal Solid Waste on the Growth of Maize (Zea Mays L.)
}

\author{
Simeon P. 0. \\ Ambah B.
}

\author{
Department of Agricultural Education \\ I saac Jasper Boro College of Education \\ Sagbama, Bayelsa State, Nigeria
}

\section{Doi:10.5901/ ajis.2013.v2n10p67}

\begin{abstract}
A pot experiment was conducted in the green house to determine the effect of municipal solid waste on the growth of maize (zea mays). Growth parameters of percentage emergence, plant height, leaf area and number of levers per plant were collect and subjected into statistical analysis, using ANOVA and fisher's L.S.D. at 5\% probability level. Plant growth parameters decreased with increase in cropping cycle. Similarly, maize grown on dumpsite soils did better than the control soil samples. It show increase in plant height, leaf area and number of leaves per plant at a range of $16.82 \mathrm{~cm}$ to $12.87 \mathrm{~cm}, 5$ to 4 and $64.69 \mathrm{~cm}$ to $59.88 \mathrm{~cm}$ for the dumpsite and control samples respectively. Soil PH, organic matter (OM), total Nitrogen (N), Phosphorus (P), Potassium (K), Calcium (Ca), Magnesium (Mg), Sodium ( $\mathrm{Na}$ ) and Effective Cat-ion Exchange Capacity (ECEC) decreased with increase in cropping cycle respectively. The Dumpsite soil sample recorded higher mean values than the control $(P<0.05)$. There is every indication that municipal solid waste is beneficial to plant if only proper and careful sorting and separation of hazardous waste is done.
\end{abstract}

Keywords: Growth, Dumpsites, Municipal, Solid and Waste.

\section{I ntroduction}

Maize (Zea mays L.) is the most important cereal crop after rice in Sub-Saharan African and one of the three most important cereal crops in the world. Maize is high yielding, easy to process, readily digested, and cost less than other cereals. This annual plant of the gramineae family is descended from a common ancestor which is unknown or disappeared (I rvine 1970). Every part of the maize plant has economic value: the grain, leaves, stalk, tassel, and cob all are used to produce a large variety of food and non food products.

In industrialized countries, maize is largely used as livestock feed and as raw material for industrial products, while in low income countries, it is mainly used for consumption. In subSaharan Africa, maize is a staple food for an estimated $50 \%$ of the population (IITA, 2006). It is an important source of carbohydrate, I ron, Vitamin B, and minerals. Africans consume maize as Starch based Porridges, paste, grits and beer. Green maize (fresh on the cob) is eaten parched, baked, roasted or boiled and plays an important role in filling the hunger gap after the dry season (IITA, 2006).

Municipal Solid Waste (MSW) are unwanted Bi-products of modern life, generated by people living in Urban areas. These are inclusive of all waste under the control of local authorities or agents acting on their behalf. Municipal Solid Waste has a compostable potential of $60-90 \%$. It's typical composition include paper, glass, wood, plastics, soils chemicals, food waste, plant debris, metal textiles and rock with the organic materials making up $50-70 \%$ of all Municipal Solid Waste 
(MSW). I deally, the compost feedstock should only contain compostable materials such as food scraps, papers, cardboard, wood, non-compostable solid waste (glass, metals, and plastics).

In general, the fewer non compostable material in the feed stock, the better finished compost will be for agricultural used (Amusan et al, 2005).

Nutrient availability to plant is strongly influenced by organic and inorganic amendments that usually increase the amount of carbon and other nutrients, especially nitrogen. Organic matter is added to soil by the incorporating plant materials, animal residue manure, sewage sludge or municipal waste. Amendments not only influence soil fertility directly, but can also affect the composition and activity of soil organisms (Carmine et al, 2004). Peter (2005) also reported that municipal solid waste has the ability of improving soils that have been cropped for many years, but which may be deficient in nutrients such as Boron, Zinc, Copper, and municipal solid waste compost mitigate such deficiencies. Stengel 1995; Aghoola 1990 also added that crop residues contain considerable quantities of major crop nutrients as well as being source of organic matter.

Other benefit include improved soil physical characteristics such as nutrient retention capacity and stimulation of microbial activities that can improved plant growth and decrease the leaching of pollutants into waste supplies. Municipal Solid Waste (MSW) compost has been used to maintain the long term productivity of agro-ecosystems and to protect the soil environment form over cropping (Carmine et al, 2004). Nutrient availability to plant is strongly influenced by organic carbon and other nutrients, especially nitrogen.

Haven looked at the apparent problems of municipal solid waste, management and provable importance to plant growth. This study was carried out to see how municipal waste can affect maize growth.

\section{Methods and Procedures}

The research work was conducted in the green house of the Teaching and Research Farm of Bayelsa State College of Arts and Science (BYCAS), Agudama-Epie, Yenagoa. Yenagoa lies between latitude 04 15" North, 05 22" South and Longitude 05 22" West and 06 45" East.

Yenagoa is one of the rapidly growing cities in Nigeria with a population over 700,000 people covering an area of about $622.80 \mathrm{~km}$ ( 62280.00 hectares). Yenagoa lies in the heaviest rainfall area in Nigeria, with heavy rain and short dry season (From November to March). The area has a humid tropical climate with a mean temperature of $30^{\circ} \mathrm{C}$ and mean annual rainfall range of $3000-4500 \mathrm{~mm}$ BSCAC (2006).

Five (5) sampling locations were established. Municipal Solid Waste was collected from the different dump sites within Yenagoa metropolis as follows:

Location 1 - Agudama-Epie

Location 2 - Tombia Road

Location 3 - Swali

Location 4 - Igbogene

Location 5 - Biogbolo

Location 2 is used by the Bayelsa State environmental Sanitation Authority for solid waste disposal. Others are used by the residence living in those areas. All the dumpsites are still active and have been used for the past ten (10) years. Apart from Location 2 that covers a large expanse of land, others are between 300-700sq meters. The waste at each dumpsite is generally unsorted and consists of all forms of agricultural, domestic, industrial and hospital waste, with a high percentage constituting mainly of domestic and house hold products.

\subsection{Sampling Procedure}

At each location municipal solid waste were randomly collected at a depth of $(0-30 \mathrm{~cm})$ with the aid of an auger, and were placed into a well labeled polythene bags and pulverized differently. Control 
samples were also collected from fallow plots, at each location from a distance of $100 \mathrm{~m}$ away from each dumpsite.

\subsection{Planting}

The Municipal Solid Waste and soil sample from the fallow plots were sent to the laboratory for analysis. The samples were air dried and sieved to pass through $2 \mathrm{~mm}$ sieve. $50 \mathrm{~g}$ of the Municipal Solid Waste was weighed into $2 \mathrm{~kg}$ soil pulverized properly and the control sample were also weighed into 3 replicates all totaling 30 plastic buckets in the green house. The samples were kept wet daily for 20days before planting was done. This experiment was repeated the second time, after ten (10) days of fallow with constant watering to keep the soil samples at field capacity. The test crop (maize) was sourced from the International Institute of Tropical Agriculture (IITA), Yenagoa office, Bayelsa State. Four (4) seed were planted and later thinned down to two (2) stands with regular watering.

\subsubsection{Experimental Design/Tools for Data Analysis}

The complete Randomized Block Design was used, and ANOVA (fisher's L.S.D.) was used to compare mean (Wahua, 1999). And the following plant parameters were collected for data analysis.

\subsubsection{Percentages Emergence}

Crop emergence was analyzed as a percentage of seedlings of 4 and 5 days after planting (DAP) to the actual number of seeds planted. Plants that survived were counted.

\subsubsection{Number of leaves}

The numbers of leaves per plant were counted starting from 2 to 4 weeks after the date of planting (WAP).

\subsubsection{Plant Height and Leaf Area}

Plant height per plant were measured from the base of the plant to it tip. Leaf areas per plant were determined non-destructively by length $\mathrm{x}$ width method described by Savena and Singh (1965) using Linear equation. Leaf Area $=0.75$ (LXW) from 2 to 4 weeks after planting (WAP).

\subsection{Soil Sampling and Analysis after planting}

The control and municipal solid waste mixed samples in the buckets were sampled at $0-7 \mathrm{~cm}$ depth 6 weeks after planting ( 6 WAP). The respective soil samples were transferred for Laboratory analysis from the green house. Samples were air-dried and ground to pass a $2 \mathrm{~mm}$ sieve prior to chemical analysis. Soil $\mathrm{P}^{\mathrm{H}}$ was determined on a 1:1 soil: $\mathrm{H}_{2} \mathrm{O}$ solution with a glass electrode $\mathrm{P}^{\mathrm{H}}$ meter according to the procedure of Tel and Rao (1982). Organic matter was determines using a modification of the method of Walkley and Black (1934). Total nitrogen was determined using a Techno icon auto analyzer (Technicon AAll) after digesting the sample with a mixture of concentrated Orthophoric and sulfuric acid in a tecato digester. Available phosphorus in the soil was determined by the Bray-1 method using the Technico auto analyzer (Tel and Rao 1982). Exchangeable Cations were extracted with $\mathrm{NH}_{4} \mathrm{O} 4 \mathrm{C}+0.00 \mathrm{~lm}$ EDTA at 20:15 fresh soil: extractant ratio. The concentration of Calcium and magnesium in the extracts were determined with Atomic 
Absorption Spectophotometer (AAS) were measured with a flame photometer. The Effective Cation Exchange Capacity (ECEC) was calculated by the sum of exchangeable cat ions and exchangeable acidity, expressed in an $\mathrm{cmol} \mathrm{kg}-1$ soil.

\section{Result}

\subsection{Plant Growth Parameters.}

The inclusion of municipal waste in the growth of maize was aimed at improving a source of nitrogen $(\mathrm{N})$ to soil. The study reveals that there was significant effect of cropping cycle and the municipal solid waste from the various dumpsites on the emergence of maize see fig 1 and plate 1 to 10 .

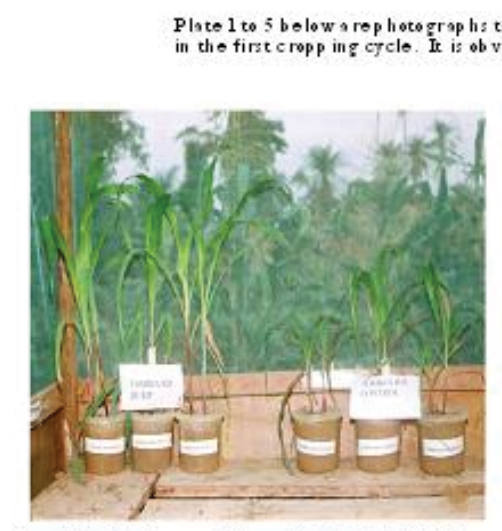

Pbtel: Tombis Dump and Contro I(T0um a Tousc)

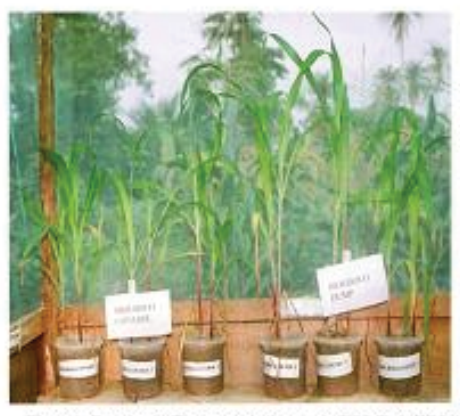

Plste 2: B is og ob Dump and Control (BIOD a BIOC
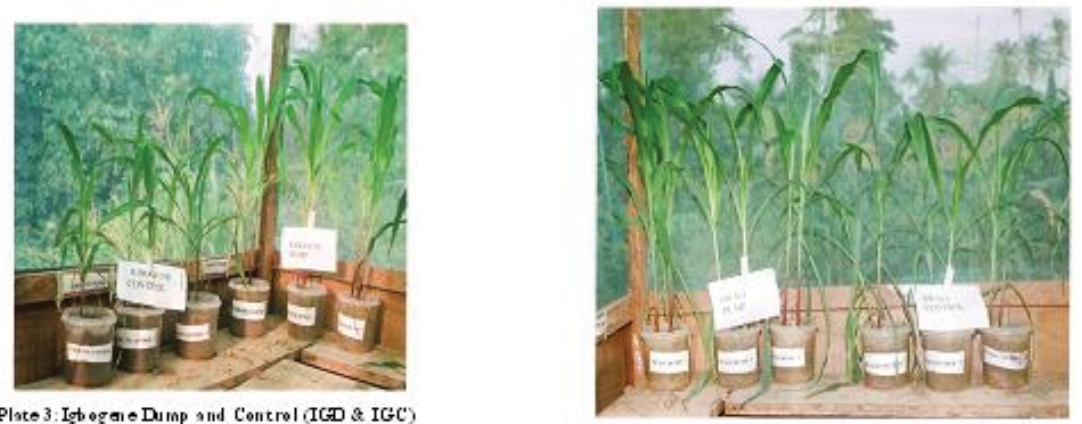

Plste 3: Igbegaie Dump and Control (IGD \& IGC)

Pbte 4: Sws li Dump and Contro (s wD a s WC)

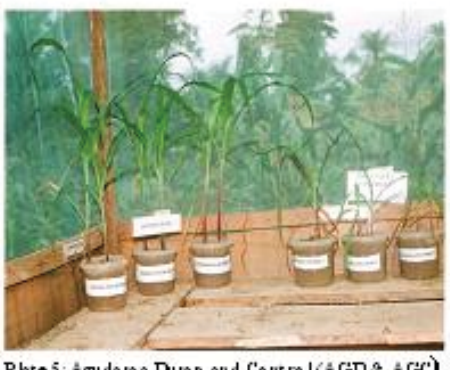




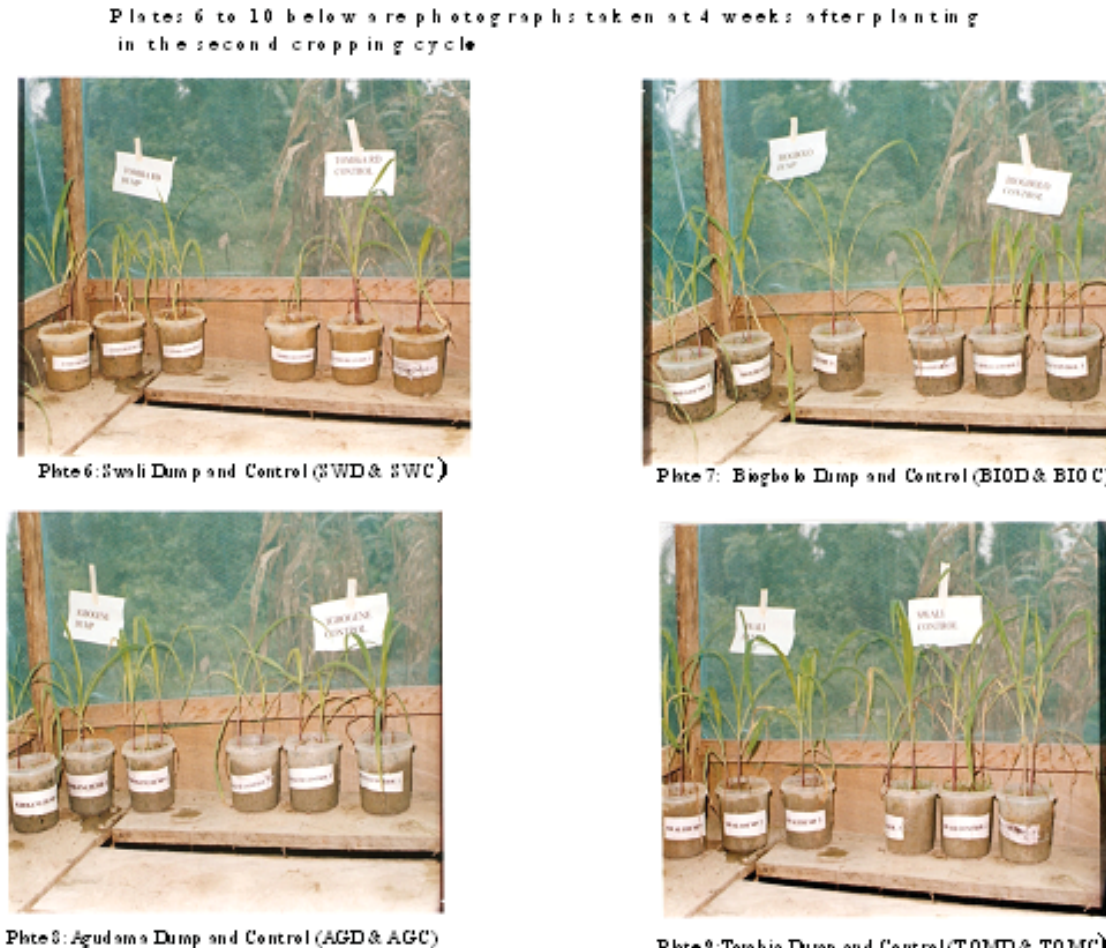

Phte 9:Tonb is Dump and Control(T 0um a Tousc)

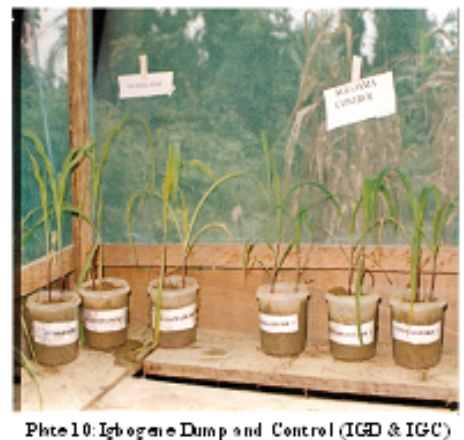

\subsection{Leaf Number, Area and Plant Height.}

The effect of cropping cycle has a significant difference on leaf number, area and plant height.

The leaf area, number and plant height decreased with increase in the cropping cycle see fig 2-4. There is also a significant difference between the various maize growth parameters. Maize grown on municipal solid waste mixed sample did better than the control samples. See table 1 and plate 1 to 10 . This is in consonant with earlier work carried out by (Carmine et al, 2004). Nutrient availability to plant is strongly influenced by organic and inorganic amendments that usually increase the amount of carbon and other nutrients; especially nitrogen. 

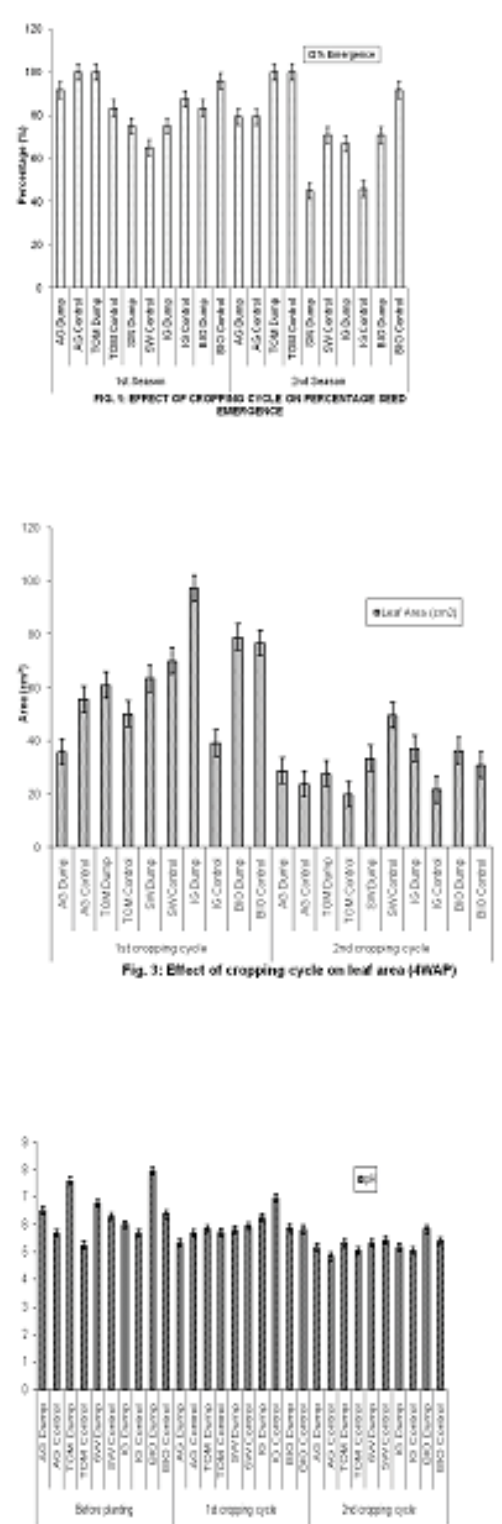

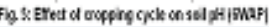
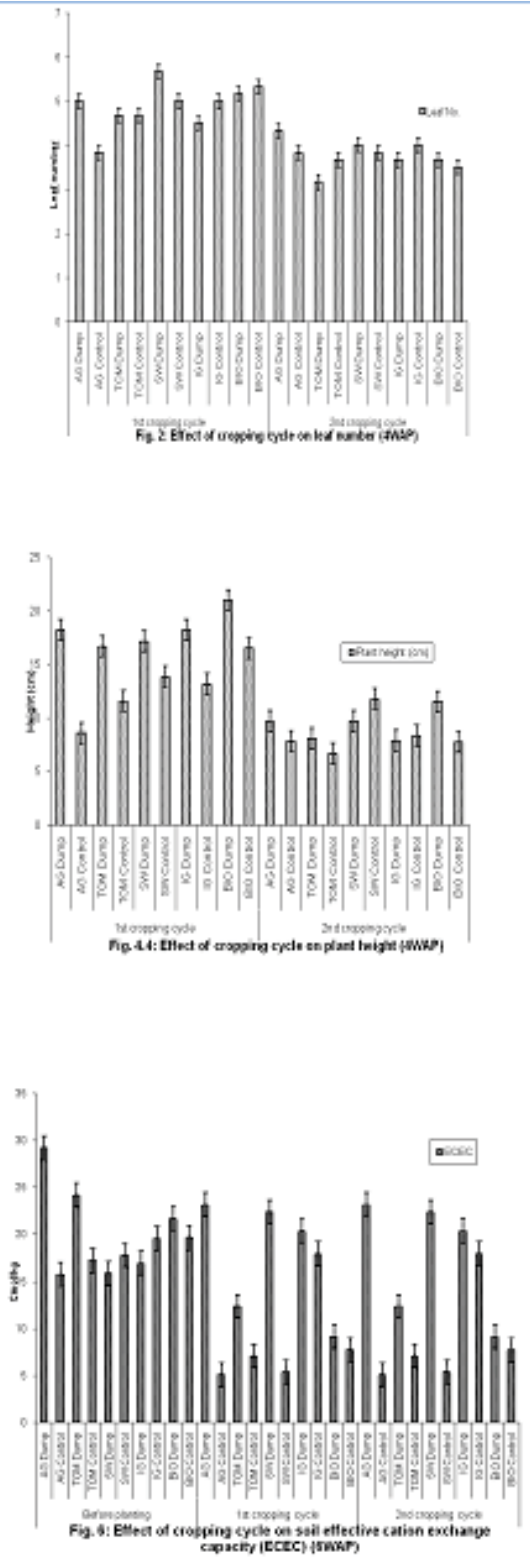

Table 1: Effect of Municipal Solid Waste on Maize Growth

\begin{tabular}{|c|c|c|c|c|}
\hline Dumpsite & $\%$ Emergence & Plant Height $(\mathrm{cm})$ & Leaf No. & Leaf Area $(\mathrm{cm})$ \\
\hline AGD & 84.42 & 13.98 & 5 & 32.27 \\
\hline AGC & 89.58 & 8.26 & 4 & 39.72 \\
\hline TOMD & 100 & 12.40 & 4 & 44.36 \\
\hline TOMC & 91.67 & 9.15 & 4 & 34.94 \\
\hline SWD & 99.09 & 13.47 & 5 & 48.41 \\
\hline SWC & 68.18 & 12.87 & 4 & 59.88 \\
\hline IGD & 70.83 & 16.82 & 4 & 64.69 \\
\hline
\end{tabular}




\begin{tabular}{|c|c|c|c|c|}
\hline IGC & 66.67 & 13.09 & 5 & 30.32 \\
\hline BIOD & 77.08 & 16.28 & 4 & 57.62 \\
\hline BIOC & 93.75 & 12.16 & 4 & 53.72 \\
\hline LSD & 15.0 & 1.74 & 0.4 & 10.32 \\
\hline
\end{tabular}

$P(<0.05)$ Agudama dumpsite and control (AGD \& AGC), Tombia dumpsite and control (TOMD \& TOMC), Swali dumpsite and control (SWD \& SWC), Igbogene dumpsite and control (IGD \& IGC) and Biogbolo dumpsite and control (BIOD \& BIOC).

Table 2: Effect of Municipal Solid Waste on Soil Physiochemical

\begin{tabular}{|c|cccccccccc|c|}
\hline Dumpsite & $\mathrm{pH}$ & $\mathrm{N}(\%)$ & $\mathrm{P}(\mathrm{ppm})$ & $\mathrm{O} . \mathrm{M} .(\%)$ & $\mathrm{Ca} \mathrm{mol} / \mathrm{kg}$ & $\mathrm{Mg} \mathrm{cmol} / \mathrm{kg}$ & $\mathrm{K} \mathrm{cmol} / \mathrm{kg}$ & $\mathrm{Na} \mathrm{cmol} / \mathrm{kg}$ & $\mathrm{ECEC}-\mathrm{cmol} / \mathrm{kg}$ \\
\hline AGD & 5.68 & 0.10 & 15.00 & 3.94 & 17.92 & 5.53 & 0.16 & 0.13 & 25.16 \\
\hline AGC & 5.40 & 0.09 & 5.00 & 3.67 & 6.60 & 1.70 & 0.08 & 0.07 & 8.61 \\
\hline TOMD & 6.25 & 0.08 & 12.00 & 3.31 & 10.83 & 3.33 & 0.17 & 0.71 & 16.28 \\
\hline TOMC & 5.34 & 0.07 & 7.67 & 3.08 & 6.91 & 1.93 & 0.11 & 0.05 & 10.44 \\
\hline SWD & 5.97 & 0.11 & 7.00 & 4.45 & 14.93 & 3.49 & 0.14 & 0.09 & 20.19 \\
\hline SWC & 5.87 & 0.05 & 5.33 & 2.09 & 6.16 & 1.42 & 0.09 & 0.05 & 9.48 \\
\hline IGD & 5.81 & 0.21 & 17.67 & 6.98 & 12.88 & 4.14 & 0.13 & 0.13 & 19.21 \\
\hline IGC & 5.89 & 0.13 & 10.67 & 3.00 & 13.25 & 3.42 & 0.09 & 0.05 & 18.47 \\
\hline BIOD & 6.55 & 0.14 & 19.00 & 6.41 & 8.59 & 3.06 & 0.09 & 0.07 & 13.30 \\
\hline BIOC & 5.86 & 0.07 & 11.22 & 3.04 & 7.28 & 2.69 & 0.09 & 0.07 & 11.67 \\
\hline LSD & 0.02 & 0.02 & 0.74 & 0.03 & 0.89 & 0.17 & 0.01 & 0.01 & 0.02 \\
\hline
\end{tabular}

$\mathrm{P}(<0.05)$ Agudama dumpsite and control (AGD \&AGC), Tombia dumpsite and control (TOMD \& TOMC), Swali dumpsite and control (SWD \& SWC), Igbogene dumpsite and control (IGD \& IGC) and Biogbolo dumpsite and control (BIOD \& BIOC).

\subsection{Municipal Solid Waste Effect on Soil Properties.}

Earlier studies have shown that organic matter is added to soil by incorporating plant materials, animal residue manure, sewage sludge or municipal waste (carmine et al, 2004). Stengel 1995; Aghoola 1990 also added that crop residues contain considerable quantities of major crop nutrients as well as being source of organic matter. Some changes were observed of some available plant nutrients in the soil between before planting, first and second cropping cycle soil samples see. Fig 5-11 and Table 2. The effect of various cropping cycles on soil properties differs significantly. Soil $\mathrm{P}^{\mathrm{H}}$ reduced with increase in the cropping cycle that is the soil samples analyzed become increasingly acidic from before planting to the second cycle of cropping ECEC and phosphorus level also reduces from before planting to the second cropping cycle. For the organic matter, Nitrogen, Potassium and Sodium level in the various soil samples analyzed before planting commenced record higher levels and gradually reduced from first cropping cycle to the application of municipal waste had been used up by the maize grown in the first cycle. This is also in line with an earlier study carried out by (I kpe et al, 1999) soil nutrients increased proportionally with increase in soil amendment application.

The various cropping cycles had significant effect on the level of calcium and magnesium levels in the soil samples analyzed. The level of both $\mathrm{Ca}$ and $\mathrm{Mg}$ levels decreased with increase in the cropping cycles.

\section{Conclusion}

The result of this study shows the importance of municipal solid waste in the growth of maize. The application of municipal solid waste had a significant effect on the performance of the growth parameters (plant height leaf area and number of leaves per plant measured with virtually all 
dumpsites doing better than their control. Also soil chemical properties (PH, N.P.K, OM, Ca, Mg, Na and (ECEC) measured decreased with increase in the cropping cycle. So there is every need to add municipal solid waste to soil to improve it fertility status, provided the materials are free from poisonous substances.

\section{References}

Agboola A.A. 1990. Organic matter and soil fertility management in humid tropics of Africa. In: Pashparajah E. and Lathemi M.(eds) organic matter management and Bantok, Thailand; International Board for sol Research and Management, IB Ray. Proceeding No. 10:23-244.

Amusan, A. A, I ge D. V, Olawale, R. (2005): Characteristics of Soil Crops uptake of metal in Municipal Waste dumpsites in Nigeria. J. Hum Col; 17 (3) 167-171

Carmine Crecchio, Magda Curci, Maria, D.R, Pizzigallo, Patrizia Riccicutti, PaciFCo Ruggiero (2004): Effects of Municipal Solid Waste compost Amendments on Soil Enzyme Activities and Bacteria Genetic Diversity. Pp. 1595-1605.

I kpe, F.N. Powell J.M. Isirimah, N.O. Wahua T.A.T. and Ngodigha. E.M. 1999. Effects of primary tillage and soil amendment practices on peal millet yield and nutrient uptake in the Sahel of West Africa. Experiential Agriculture 35:437-448.

International Institute of Tropical Agriculture (IITA) (2006): Research to nourish Africa. August Ppl-7.

Irvine, F.R. (1970: West African Crops. Oxford University Press, Waton Street, OxFord OX26DP. Pp 125.

Peter, B. Woodbury (2005): Municipal Solid Waste composting potential effects of Heavy metal in Municipal Solid Waste compost and the environment. Boyce Thompson Institution For Plant Research at Cornell University. Municipal Solid Waste Fact Sheet 4 of 7.

Nyle, C. Brady and Ray. R. Well (2002): The nature and properties of soils 13th Edition. Saurabh Printers Pvt. Ltd, India: 105-113.

Saxena, M. C and Singh, Y. (1965): A note on leaf Area Estimation intact Maize leaves, India Journal of Agnonomy. Vol.24, pp.108-159.

Stangel, P.J . 1995, Nutrient cycling and its importance in sustaining crop-livestock system in SubSahavah Africa: An overview. In Powell J.M. Fernandez - Rivera. S., Williams T.O, and Nutrient cycling in mixed Farming systems of Sub-Sahara Africa, Pp 37-62.

Tel, and P.V. Rao. 1982. Automated and semi-automated methods for soil and plant analysis. IITA Manual series N07, International Institute of Tropical Agriculture Ibadan, Nigeria.

Wahua, T. A. T. (1999): Applied Statistics for Scientific Studies. Africa - Link Books, University of Ibadan Pp. 124-141.

Walkley, J.J. and A. Black (1934): An Examination of the different methods of determining Soil organic Matter and a Proposed Modification of the Acid Titration Method Sc.37:29,38. 